\title{
Towards a New Treaty on Business and Human Rights
}

\author{
Olivier DE SCHUTTER*
}

\begin{abstract}
This article examines the legal as well as political feasibility of four potential options for a legally-binding international instrument in the area of business and human rights. The four options that the open-ended intergovernmental working group may wish to consider while negotiating an instrument are: (i) to clarify and strengthen the states' duty to protect human rights, including extraterritorially; (ii) to oblige states, through a framework convention, to report on the adoption and implementation of national action plans on business and human rights; (iii) to impose direct human rights obligations on corporations and establish a new mechanism to monitor compliance with such obligations; and (iv) to impose duties of mutual legal assistance on states to ensure access to effective remedies for victims harmed by transnational operations of corporations. As these options are not mutually exclusive, the author argues that a hybrid instrument building on elements of the first and the fourth option may be the best way forward both in terms of political feasibility and improving access to effective remedies for victims.
\end{abstract}

Keywords: access to effective remedies, corporate veil, extraterritorial duty to protect, international treaty, mutual legal assistance

\section{INTRODUCTION}

On 26 June 2014 the Human Rights Council (HRC) adopted a resolution calling for the establishment of an open-ended intergovernmental working group (IGWG) 'to elaborate an international legally-binding instrument to regulate, in international human rights law, the activities of transnational corporations and other business enterprises'. ${ }^{\text {The }}$ resolution was tabled by Ecuador and South Africa, and it was co-sponsored by Bolivia, Cuba, and Venezuela. Although strongly supported by an impressive coalition of civil society organizations who formed a 'Treaty Alliance' in support of a binding

* Professor at the University of Louvain (UCL) and at Sciences Po (Paris); former United Nations Special Rapporteur on the Right to Food (2008-2014); and Member of the Committee on Economic, Social and Cultural Rights. The positions taken in this article reflect the personal opinions of the author and should not be construed as representing the views of the Committee on Economic, Social and Cultural Rights.

1 Human Rights Council, 'Elaboration of an International Legally Binding Instrument on Transnational Corporations and Other Business Enterprises with Respect to Human Rights', A/HRC Res. 26/9 (26 June 2014), para. 9. 
treaty ${ }^{2}$ and despite gaining support from a plurality within the Human Rights Council, the proposal was highly divisive: within the 47-members-large HRC, it was supported by 20 member states ${ }^{3}$ and opposed by 14 states (including the United States and the Member States of the European Union), ${ }^{4}$ whereas 13 member states of the HRC abstained. ${ }^{5}$

In striking contrast, it is by consensus that, on the following day, the HRC adopted a resolution tabled by Argentina, Ghana, Norway, and Russia, ${ }^{6}$ that explicitly built on the process launched by the Guiding Principles on Business and Human Rights (Guiding Principles) endorsed by the HRC in 2011. ${ }^{7}$ This resolution 'call[ed] upon all business enterprises to meet their responsibility to respect human rights in accordance with the Guiding Principles'. 8 It also expressed a strong support for the work of the Working Group on Business and Human Rights, the body of five independent experts established in 2011 to support the implementation of the Guiding Principles. ${ }^{9}$ The resolution encourages the Working Group to provide for the adoption by states of national action plans on business and human rights, and to promote 'the sharing of legal and practical measures to improve access to remedy, judicial and non-judicial, for victims of businessrelated abuses, including the benefits and limitations of a legally binding instrument': the Working Group is tasked to prepare a report on how to achieve this, for consideration by the HRC at its thirty-second session to be held in June-July $2016 .{ }^{10}$

This article assesses the prospects of a new, legally-binding instrument in the area of business and human rights. ${ }^{11}$ It argues that the gap between the states supporting the

\footnotetext{
2 Some 600 non-governmental organizations have formed the Treaty Alliance (or Global Movement for a Binding Treaty). See 'Enhance the International Legal Framework to Protect Human Rights from Corporate Abuse', http://www. treatymovement.com/statement/ (accessed 15 July 2015). Notably, however, neither Amnesty International nor Human Rights Watch, two major international human rights non-governmental organizations, have formally joined the Treaty Alliance.

3 Algeria, Benin, Burkina Faso, China, Congo, Cote d'Ivoire, Cuba, Ethiopia, India, Indonesia, Kazakhstan, Kenya, Morocco, Namibia, Pakistan, Philippines, Russia, South Africa, Venezuela, and Vietnam voted in favour of the resolution.

4 The states who voted against the resolution are Austria, Czech Republic, Estonia, France, Germany, Ireland, Italy, Japan, Montenegro, South Korea, Romania, Macedonia, the United Kingdom, and the United States of America.

5 Argentina, Botswana, Brazil, Chile, Costa Rica, Gabon, Kuwait, Maldives, Mexico, Peru, Saudi Arabia, Sierra Leone, and the United Arab Emirates abstained.

6 Human Rights Council, 'Human Rights and Transnational Corporations and Other Business Enterprises', A/HRC/ Res 26/22 (27 June 2014) (Resolution 26/22).

7 Human Rights Council, 'Human Rights and Transnational Corporations and Other Business Enterprises', A/HRC/ Res 17/4 (16 June 2011), endorsing 'Guiding Principles on Business and Human Rights: Implementing the United Nations "Protect, Respect and Remedy" Framework', A/HRC/17/31 (21 March 2011).

8 Resolution 26/22, note 6, para. 3.

9 The Working Group on the issue of transnational corporations and other business enterprises and human rights was established by Resolution 17/4 adopted by the UN Human Rights Council in June 2011. Resolution 26/22 extends its mandate for another three years, for the period 2014-2017. Human Rights Council, 'Human Rights and Transnational Corporations and Other Business Enterprises', A/HRC/Res 26/22 (15 July 2014).

10 Resolution 26/22, note 6, para. 7.

11 It builds on previous contributions of the author, including 'Sovereignty-Plus in the Era of Interdependence: Towards an International Convention on Combating Human Rights Violations by Transnational Corporations' in Pieter Bekker, Rudolf Dolzer, and Michael Waibel (eds.), Making Transnational Law Work in the Global Economy: Essays in Honour of Detlev Vagts (Cambridge: Cambridge University Press, 2010) 245-84; and 'La responsabilité des Etats dans le contrôle des sociétés transnationales: vers une Convention internationale sur la lutte contre les atteintes aux droits de l'homme commises par les sociétés transnationales' in Isabelle Daugareilh (ed.), La responsabilité sociale des entreprises (Bruxelles: Bruylant, 2011) 707-77.
} 
proposal by Ecuador and South Africa and the other states-including all industrialized countries who are members of the OECD (Organisation for Economic Co-operation and Development) club-is less wide than the voting patterns seem to suggest. The suspicion towards the Ecuador-South Africa proposal is in fact largely a matter of perception, to be explained by the connotation attached to the initiative. Many see this proposal as an attempt to reopen a battle fought during the 1970s, when the regulation of transnational corporations (TNCs) was a major component of the attempts to establish a 'New International Economic Order', or as a resurrection of the proposal made in 2003 by the UN Sub-Commission for the Promotion and Protection of Human Rights for the adoption of a set of Norms on the Human Rights Responsibilities of Transnational Corporations and Other Business Enterprises (Draft UN Norms). ${ }^{12}$ These attempts failed due both to the resistance of the business community and of capital-exporting countries, and to a certain naïveté in transposing to corporations norms designed to be addressed to states. ${ }^{13}$

Can we learn from the mistakes commited in the past, in order to build on the momentum that has emerged for a new binding instrument on business and human rights? This article examines four options for the negotiation of such an instrument. The first two options-(i) to clarify the scope of the states' duty to protect human rights and (ii) to oblige states to present national action plans on business and human rights, demonstrating their progress in improving accountability and in aligning economic and policy incentives with legal requirements - essentially aim to strengthen the Guiding Principles endorsed by the HRC in $2011,{ }^{14}$ by transforming the recommendations they contain into binding legal obligations. The third and fourth options aim, respectively, (iii) to establish a new mechanism to monitor compliance of corporate actors with human rights obligations, and (iv) to provide for duties of mutual legal assistance to ensure adequate access to effective remedies for victims. Although these last two options are more ambitious, they too build on existing precedents in international law.

By contrasting these options, this article guides the discussion on the framework to be established, without being trapped into models inherited from the past. The four options are not necessarily mutually exclusive, however. Any internationally legally-binding instrument in the area of business and human rights could contain elements of each. In closing, this article considers which combination of these items could achieve the best balance between the need to improve the protection of victims, and the need to move towards proposals that are politically achievable.

\footnotetext{
12 Norms on the Responsibilities of Transnational Corporations and Other Business Enterprises with Regard to Human Rights, UN Doc E/CN.4/Sub.2/2003/12/Rev.2 (2003); and for the Commentary, UN Doc E/CN.4/Sub.2/2003/ 38/Rev.2 (2003). See also David Weissbrodt and Muria Kruger, 'Current Developments: Norms on the Responsibilities of Transnational Corporations and Other Business Enterprises with Regard to Human Rights' (2013) 97 American Journal of International Law 901; David Weissbrodt and Muria Kruger, 'Human Rights Responsibilities of Businesses as Non-State Actors' in Philip Alston (ed.), Non-State Actors and Human Rights (Oxford: Oxford University Press, 2005) 315. The Sub-Commission on Human Rights (as it was colloquially known) was a body of 26 independent experts advising the UN Commission on Human Rights, the intergovernmental body to which the Human Rights Council succeeded in 2007.

13 For a systematic overview, see Olivier De Schutter, 'The Challenge of Imposing Human Rights Norms on Corporate Actors' in Olivier De Schutter (ed.), Transnational Corporations and Human Rights (Oxford: Hart Publishing, 2006) 1.

14 Note 7. For a critical appraisal, see Surya Deva and David Bilchitz (eds.), Human Rights Obligations of Business. Beyond the Corporate Responsibilty to Respect? (Cambridge: Cambridge University Press, 2013).
} 


\section{Strengthening the Duty of the State to Protect Human RigHTS}

The duty of the state to protect human rights by regulating the behaviour of private (nonstate) actors is for the most part well understood, and it now belongs to the acquis of international human rights law. ${ }^{15}$ Under the International Covenant on Civil and Political Rights, the Human Rights Committee takes the view that:

the positive obligations on States Parties to ensure Covenant rights will only be fully discharged if individuals are protected by the State, not just against violations of Covenant rights by its agents, but also against acts committed by private persons or entities that would impair the enjoyment of Covenant rights in so far as they are amenable to application between private persons or entities. ${ }^{16}$

This is also the position adopted by the Committee on Economic, Social and Cultural Rights under the International Covenant on Economic, Social and Cultural Rights. ${ }^{17}$ Regional human rights courts or expert bodies under regional human rights instruments have routinely affirmed that the responsibility of the state may be engaged as a result of its failure to appropriately regulate the conduct of private persons. ${ }^{18}$

The principle is that states are expected to take all measures that could reasonably be taken, in accordance with international law, to prevent private actors from adopting conduct that may lead to human rights violations. The international responsibility of the state shall be engaged where such violations occur which the state could have prevented without imposing an unreasonable burden on such a state. The duty to protect includes a duty to provide access to remedies where a violation did take place (i.e., the preventive measures failed or were insufficient). Thus, the duty to protect corresponds to the first and (in part) the third pillar of the framework developed by the Guiding Principles. ${ }^{19}$ What would be the value of an instrument contributing to the progressive development of international law, ${ }^{20}$ by clarifying the scope of states' duty to protect human rights in situations where the harms have their source in the conduct of corporations?

15 See, for a systematic exposition, Olivier De Schutter, International Human Rights Law (Cambridge: Cambridge University Press, 2014) 427-526.

16 Human Rights Committee, 'General Comment No. 31, Nature of the General Legal Obligation Imposed on States Parties to the Covenant', CCPR/C/21/Rev.1/Add.13 (26 May 2004), para. 8.

17 'The obligation to protect requires measures by the State to ensure that enterprises or individuals do not deprive individuals of their access to adequate food'. Committee on Economic, Social and Cultural Rights, 'General Comment No. 12 (1999): The Right to Adequate Food (Art 11)', UN Doc E/C.12/1999/5, para. 15.

18 See, e.g., under the European Social Charter of the Council of Europe, European Committee of Social Rights, complaint no. 30/2005, Marangopoulos Foundation for Human Rights (MFHR) v Greece, decision on admissibility of 30 October 2005, para. 14 ('the state is responsible for enforcing the rights embodied in the Charter within its jurisdiction. The Committee is therefore competent to consider the complainant's allegations of violations, even if the State has not acted as an operator but has simply failed to put an end to the alleged violations in its capacity as regulator'); under the African Charter of Human and Peoples' Rights, African Commission on Human and Peoples' Rights, The Social and Economic Rights Action Center and the Center for Economic and Social Rights v Nigeria, Comm. No. 155/96 (2001) AHRLR 60 (ACHPR 2001) (15th Annual Activity Report) (on the duty of Nigeria to protect the Ogoni people from the impacts of the activities of oil companies in the Niger delta).

19 Guiding Principles, note 7, Principles 1-10, 25-27, and 31.

20 Building on Article 13, para. 1 of the UN Charter, Article 15 of the Statute of the International Law Commission (adopted by the General Assembly in resolution 174 (II) of 21 November 1947, as amended by resolutions 485 (V) of 12 December 1950, 984 (X) of 3 December 1955, 985 (X) of 3 December 1955 and 36/39 of 18 November 1981) makes a distinction 'for convenience' between 'progressive development' of international law as meaning 'the preparation of draft conventions on subjects which have not yet been regulated by international law or in regard to which the law has 


\section{A. An Extraterritorial Duty to Regulate Corporations}

There is one area where the Guiding Principles set the bar clearly below the current state of international human rights law: the extraterritorial human rights obligations of states, including, in particular, the duty of states to control the corporations they are in a position to influence, wherever such corporations operate. The Guiding Principles provide that 'States should set out clearly the expectation that all business enterprises domiciled in their territory and/or jurisdiction respect human rights throughout their operations' (Principle 2). Although this includes operations abroad, the Commentary to this Principle adds a qualification by stating:

At present States are not generally required under international human rights law to regulate the extraterritorial activities of businesses domiciled in their territory and/or jurisdiction. Nor are they generally prohibited from doing so, provided there is a recognized jurisdictional basis. Within these parameters some human rights treaty bodies recommend that home States take steps to prevent abuse abroad by business enterprises within their jurisdiction.

There are strong policy reasons for home States to set out clearly the expectation that businesses respect human rights abroad, especially where the State itself is involved in or support.

In contrast to this position, the United Nations treaty bodies have repeatedly expressed the view that states should take steps to prevent human rights contraventions abroad by business enterprises that are incorporated under their laws, or that have their main seat or their main place of business under their jurisdiction. The Committee on Economic, Social and Cultural Rights in particular affirms that states parties should 'prevent third parties from violating the right [protected under the International Covenant on Economic, Social and Cultural Rights] in other countries, if they are able to influence these third parties by way of legal or political means, in accordance with the Charter of the United Nations and applicable international law'. ${ }^{21}$

Specifically in regard to corporations, this committee has further stated that: 'States Parties should also take steps to prevent human rights contraventions abroad by corporations that have their main seat under their jurisdiction, without infringing the sovereignty or diminishing the obligations of host states under the Covenant'.22 By adopting such a cautious approach to the extraterritorial obligations of states, the Guiding Principles in fact may have been encouraging states reluctant to accept such obligations to challenge the interpretation of human rights treaty bodies, ${ }^{23}$ despite the

\footnotetext{
(F'note continued)

not yet been sufficiently developed in the practice of States' and 'codification' as meaning 'the more precise formulation and systematization of rules of international law in fields where there already has been extensive State practice, precedent and doctrine'.

21 Committee on Economic, Social and Cultural Rights, 'General Comment No. 14 (2000): The Right to the Highest Attainable Standard of Health (Art. 12 of the International Covenant on Economic, Social and Cultural Rights)', E/C.12/ 2000/4 (2000), para. 39; Committee on Economic, Social and Cultural Rights, 'General Comment No. 15 (2002): The Right to Water (Arts. 11 and 12 of the International Covenant on Economic, Social and Cultural Rights)', E/C.12/2002/11 (26 November 2002), para. 31.

22 Committee on Economic, Social and Cultural Rights, 'Statement on the Obligations of States Parties regarding the Corporate Sector and Economic, Social and Cultural rights' E/C.12/2011/1 (20 May 2011), para. 5.

23 In addition to the Committee on Economic, Social and Cultural Rights, see, e.g., Committee on the Elimination of Racial Discrimination, Concluding Observations: Canada, CERD/C/CAN/CO/18, para. 17, and Concluding Observations: United States, CERD/C/USA/CO/6, para. 30; and Human Rights Committee, Concluding Observations: Germany, CCPR/C/DEU/CO/6, para. 16.
} 
support the position of these bodies received both from legal doctrine and civil society, ${ }^{24}$ and from the International Court of Justice itself. ${ }^{25}$

Given the weak formulation chosen in the Guiding Principles as regards the extraterritorial implications of the duty to protect, a legally-binding instrument that would clarify the content of the state's duty to protect human rights could be explicit about the extraterritorial reach of this duty, in order to dispel any such confusion as might have been created as a result. This would essentially consist in imposing on the state concerned a duty to protect human rights by regulating the corporations over which the state may exercise influence, by any means compatible with international law.

The competence of the state to regulate the conduct of its nationals abroad is well established under international law, which in this regard refers to the principle of active personality. ${ }^{26}$ The implication is that a state could be sujected to a duty to protect human rights as regards corporations that are registered under its laws, have their principal place of business under the state's jurisdiction, or have located their central place of administration on the state's territory. In the absence of any particular mode of determination of the nationality under international law, there is of course a risk that the modes of determination of the nationality of the corporation will be manipulated in order to allow a state, relying on the principle of active personality, to extend its jurisdiction to extraterritorial situations_-including acts adopted by companies incorporated abroadwhich it might otherwise be prohibited to reach under international law. ${ }^{27}$ However, the criteria listed above are generally accepted, denoting a sufficiently effective link between the state and the corporation to justify the exercise of state jurisdiction.

A more radical solution would be for the new instrument to impose on the states parties that they control corporations over which they can exercise jurisdiction, including corporations established under the laws of another (host) state that are managed, controlled, or owned, by legal or natural persons considered to have the 'nationality' of the state concerned, because they are incorporated under the jurisdiction of that state, or have their principal place of business or central administration on the territory of that state.

24 The Maastricht Principles on the Extraterritorial Obligations of States in the Area of Economic, Social and Cultural Rights, adopted in Maastricht on 28 September 2011 by a number of human rights experts, non-governmental organizations, and academic research institutes, testify to the growing consensus around this requirement. See Olivier De Schutter et al, 'Commentary to the Maastricht Principles on Extraterritorial Obligations of States in the Area of Economic, Social and Cultural Rights' (2012) 34 Human Rights Quarterly 1084, at 1084-1171; Fons Coomans and Rolf Künnemann (eds.), Cases and Concepts on Extraterritorial Obligations in the Area of Economic, Social and Cultural Rights (Antwerp: Intersentia, 2012); Malcolm Langford et al (eds.), Global Justice, State Duties. The Extraterritorial Scope of Economic, Social and Cultural Rights in International Law (Cambridge: Cambridge University Press, 2013) (as regards the duty of the state to regulate corporations, see in particular the chapter by Smita Narula).

25 The International Court of Justice has affirmed the extraterritorial reach of human rights instruments on a number of occasions. Most noteworthy in this regard are its Advisory Opinion on the construction by Israël of a wall to protect its territory from potential incursions by terrorists (Advisory Opinion, Legal Consequences of the Construction of a Wall in the Occupied Palestinian Territory, 9 July 2004, para. 109) and its judgment concerning armed activities in the DRC (Armed Activities on the Territory of the Congo (Democratic Republic of the Congo v Uganda), judgment of 19 Dec. 2005, paras. 178-80 and 216-17.

26 See, e.g., Restatement (Third) of the Foreign Relations Law of the United States, Vol. 2 (Washington: American Law Institute Publishers, 1987), § 402(2) ('a state has jurisdiction to prescribe law with respect to ... (2) the activities, interests, status, or relations of its nationals outside as well as within its territory').

27 Yitzhak Hadari, 'The Choice of National Law Applicable to the Multinational Enterprises' (1974) Duke Law Journal 1, at 16 (noting that the determination by the US of the rules of the nationality of the corporation has occasionally been relied upon in order to allow for an extension of US law to corporations whose main connections may be to foreign countries). 
Such a solution would arguably be consistent with existing international law. The practice of determining the nationality of a corporation on the basis of the nationality of its shareholders, particularly of the nationality of a controlling parent company, while not usual, is not unknown. For instance, while the practice of the United States (US) has generally been to determine the nationality of a corporation on the basis of the company's place of incorporation, ${ }^{28}$ it is occasionally defined by reference to the nationality of its owners, managers, or other persons deemed to be in control of its affairs. This is the case, in particular, in the tax area; ${ }^{29}$ but there seems to be no reason why this could not be extended to other domains. It would therefore not come as a surprise if the American Law Institute's Third Restatement on Foreign Relations Law does not exclude the regulation of foreign corporations, i.e., corporations organized under the laws of a foreign state, 'on the basis that they are owned or controlled by nationals of the regulating state'. ${ }^{30}$ Whether such exercise of extraterritorial jurisdiction would also be diplomatically acceptable, however, is doubtful, as it would be interpreted as questioning the sovereign right of host states to regulate investment under their (territorial) jurisdiction.

The more modest approach outlined above may therefore be preferable. In this approach states parties to the new international instrument would impose on parent corporations domiciled in that state an obligation both to comply with human rights wherever they operate (i.e., even if they operate in other countries), and to impose compliance with such norms on the different entities it controls (its subsidiaries, or even in certain cases its business partners). Under this approach, sometimes referred to as parent-based extraterritorial regulation, no question of extraterritoriality arises: the parent corporation is imposed certain obligations by the state of which it has the 'nationality' (or where it is domiciled), and the impacts on situations located outside the national territory are merely indirect, insofar as such impacts would result from the parent company being imposed an obligation to control its subsidiaries, or to monitor the supply chain.

\section{B. Overcoming the Problem of the Corporate Veil}

This approach would also help in overcoming a second problem that the Guiding Principles have not adequately addressed: the corporate veil. As noted above, the Guiding Principles include a human rights due diligence requirement as part of the corporate responsibility to respect human rights. However, the extent to which this requirement imposes a responsibility on a corporation to ensure that other corporate entities with which it has an investment link comply with human rights remains unspecified. Yet, in practice, in the absence of such a duty being imposed, victims of transnational corporate human rights abuses may face important hurdles. Within a

\footnotetext{
28 Restatement (Third) of the Foreign Relations of the United States, note 26 at 213 (note 5). On this question, see generally Linda Mabry, 'Multinational Corporations and US Technology Policy: Rethinking the Concept of Nationality' (1999) 87 Georgetown Law Journal 563, at 563-631.

29 As noted by Mabry, this allows the aggregation of the different corporate entities integrated within the multinational group and treating them as one single enterprise whose benefits will be taxed on a consolidated basis, reflecting the operations of both domestic and foreign subsidiaries. Mabry, note 28, 567. She refers to Container Corp. of Am. $v$ Franchise Tax Bd. 463 US 159 (1983).

30 Restatement (Third) of the Foreign Relations of the United States, note 26, § 414.
} 
multinational corporation, the parent (controlling) corporation on the one hand and its (controlled) subsidiary on the other, form two distinct legal entities, each with their own juridical personalities. According to the doctrine of limited liability, the shareholders in a corporation may not be held liable for the debts of that corporation beyond the level of their investment. ${ }^{31}$ This makes it difficult for victims of the conduct of the subsidiary to seek reparation by filing a claim against the parent company before the national jurisdiction of the home state of that company. In theory, three paths may be explored in order to overcome the problem of the separation of legal entities.

The classical 'piercing the corporate veil' approach requires a close examination of the factual relationship between the parent and the subsidiary in order to identify whether the nature of that relationship is not more akin to the relationship between a principal (the parent) and an agent (the subsidiary), or whether there are other reasons to suspect that the separation of corporate personalities does not correspond to economic reality. Thus, in exceptional circumstances, the courts in the US (and elsewhere) will allow claimants to establish that the parent company exercises such a degree of control on the operations of the subsidiary that the latter cannot be said to have any will or existence of its own, ${ }^{32}$ and that treating the two entities as separate (and thus allowing the parent to shield itself behind its subsidiary) would sanction fraud or lead to an inequitable result. ${ }^{33}$ In such cases, the 'piercing of the corporate veil' will be admitted, on the basis that the subsidiary has been a mere instrument in the hands of the parent company ${ }^{34}$ or that the parent and the subsidiary are 'alter egos'. ${ }^{35}$

Alternatively, it may be shown that the subsidiary was acting in a particular case as the agent of the parent company. ${ }^{36}$ This will be allowed, again in rather exceptional circumstances, where the parent company controls the subsidiary, and where both parties agree that the subsidiary is acting for the agent. ${ }^{37}$ An example is the reasoning followed in the case of Bowoto v Chevron Texaco, where Judge Illston concluded that CNL, the subsidiary of Chevron in Nigeria, which allegedly had acted in concert with the Nigerian

31 'Normally the corporation is an insulator from liability on claims of creditors. The fact that incorporation was desired in order to obtain limited liability does not defeat that purpose. Limited liability is the rule, not the exception'. Anderson v Abbott 321 US 349, 362 (1944) (citations omitted). See also Burnet v Clark 287 US 410, 415 (1932) ('A corporation and its stockholders are generally to be treated as separate entities').

32 Taken alone, neither majority or even complete stock control, nor common identity of the parent's and the subsidiary's officiers and directors, are sufficient to establish the degree of control of required. What is required is 'control $[\ldots]$ of policy and business practice in respect to the transaction attacked so that the corporate entity as to this transaction has at the time no separate mind, will or existence of its own' (Lowenthal v Baltimore \& Ohio RR Co. 287 NYS 62, 76 (NY App. Div.), cited by Philip I Blumberg, 'Accountability of Multinational Corporations: The Barriers Presented by Concepts of the Corporate Juridical Entity' (2001) 24 Hastings International and Comparative Law Review 297, 304.

33 See Taylor v Standard Gas Co. 306 US 307, 322 (1939) ('the doctrine of corporate entity, recognized generally and for most purposes, will not be regarded when to do so would work fraud or injustice').

34 Chicago, M \& St P R Co. v Minneapolis Civic and Commerce Assn 247 US 490, 501 (1918) (principles of corporate separateness 'not applicable where stock ownership has been resorted to, not for the purpose of participating in the affairs of a corporation in the normal and usual manner, but for the purpose [...] of controlling a subsidiary company so that it may be used as a mere agency or instrumentality of the owning company').

35 See, e.g., United States v Betterfoods 524 US 51 (1998).

36 As Justice (then Judge) Cardozo summarized in Berkey v Third Avenue R. Co. 244 NY 84, 95: 'Dominion may be so complete, interference so obtrusive, that by the general rules of agency the parent will be a principal and the subsidiary an agent'.

37 Blumberg, note $32,307$. 
military to violently suppress protests against Chevron's activities in the region, could be considered as the agent of Chevron, in view of the volume, content, and timing of communications between Chevron and CNL, notably on the day of a protest when 'an oil platform was taken over by local people'. ${ }^{38}$ These and other indicia showed that Chevron 'exercised more than the usual degree of direction and control which a parent exercises over its subsidiary'. 39

In order to establish that the corporate form has been abused-by a parent artificially seeking to shield itself from liability by establishing a subsidiary which has in fact no existence of its own - or that the subsidiary has been acting in fact as the agent of the parent corporation, claimants have to demonstrate that the separation of legal personalities is a mere legal fiction to which the economic reality does not correspond. $^{40}$ This approach may, however, constitute a source of legal insecurity, since there is no closed list of circumstances allowing the 'piercing of the veil', and such circumstances are not hierarchized. Moreover, complainants seeking to invoke the indirect liability of the parent corporation for the acts of its subsidiary face a heavy burden under this approach: in fact, very few such attempts to 'pierce the veil' end up succeeding. ${ }^{41}$

A second approach (although it could be seen as a variation on the first) is based on the idea that multinational corporations are groups of formally separate entities, but whose interconnectedness is such that it may be justified to establish a presumption according to which any act committed by one subsidiary of the group should be treated as if it were adopted by the parent. ${ }^{42}$ Here, a TNC is seen as 'a conglomeration of units of a single entity, each unit performing a specific function, the function of the parent company being to provide expertise, technology, supervision and finance. Insofar as injuries result from negligence in respect of any of the parent company functions, then the parent should be liable' ${ }^{43}$ This 'integrated enterprise' approach is thus in line with the contemporary evolution of multinational firms. The ability of the multinational firm to move large

\footnotetext{
38 Bowoto v Chevron Texaco, No. C 99-2506 SI, 2004 US Dis LEXIS 4603 (ND, Cal 2004). The case is discussed by Sarah Joseph, Corporations and Transnational Human Rights Litigation (Portland: Hart Publishing, 2004) 132-3.

39 Bowoto $v$ Chevron Texaco, ibid.

40 See, e.g., Labor Board v Deena Artware 361 US 398, 402 (1960).

41 Since the New Deal period, therefore, an alternative line of cases has emerged in the US courts, which has led a number of these courts to set aside the classical tests for allowing the piercing of the corporate veil in order to ensure that the legislative policy will not be defeated by the choice of corporate forms. See, e.g., Anderson v Abbott 321 US 349, 362-3 (1944) ('the interposition of a corporation will not be allowed to defeat a legislative policy, whether that was the aim or only the result of the arrangement'); Bangor Punta Operations, Inc v Bangor \& Aroostook R Co. 417 US 703 , 713 (1974) ("the corporate form may be disregarded in the interests of justice where it is used to defeat an overriding public policy'); First National City Bank v Banco Para El Comercio Exterior de Cuba 462 US 611, 630 (1983) (refusing to 'give effect to the corporate form where it is interposed to defeat legislative policies'). However, the abandonment of the classical 'piercing the corporate veil' test has been piecemeal rather than systematic, and this has not contributed to legal certainty.

42 This was the approach adopted in the Amoco Cadiz Oil Spill Case by the District Court of Illinois, even in the absence of any legislative mandate, in order to conclude that the parent corporation should be held liable for environmental damage caused by an oil spill from a tanker off the coast of France. Amoco Cadiz Oil Spill 1984 AMC 2123. The US legislator occasionally established the same presumption, in order to extend the extraterritorial reach of legislation by also addressing the subsidiaries of US firms. See, e.g., Title VII of the 1964 Civil Rights Act, 42 USC $\S 2000$ e, or the 1990 Americans with Disabilities Act, 42 USC $\$ 12112$ (c)(2)(A).

43 Richard Meeran, 'The Unveiling of Transnational Corporations' in Michael K Addo (ed.), Human Rights Standards and the Responsibility of Transnational Corporations (The Hague: Kluwer Law International, 1999) 170.
} 
volumes of goods swiftly and cost-effectively, as well as the standardization of products across the globe, has transformed the classical understanding of the relationship between the parent and the subsidiary. In many cases, the multinational appears as a co-ordinator of the activities of its subsidiaries, which function as a network of organizations operating along functional lines rather than according to geographical specialization. $^{44}$ In this process, the new organizational structures 'give global corporate managers authority over country and regional managers'; incentive systems are devised to 'encourage cooperation among employees working for different affiliates'; and 'programs and practices designed to instill in diverse groups of employees scattered around the globe a common sense of purpose and common methods of operation ${ }^{45}$ : in sum, the head office reasserts its role, as the integration of the group is deepened.

Finally, a third avenue consists of abandoning altogether the idea of linking the behaviour of the subsidiaries to that of the parent, and focusing instead on the direct liability of the parent company arising from the failure to exercise due diligence in controlling the acts of the subsidiaries it may exercise control upon. The liability of the parent corporation thus relates not only to the actions of parent firm, but also to its omissions. Indeed, a regime in which the liability of the parent company would be engaged for its actions alone (for the role it played in aiding and abetting the subsidiary to commit the alleged violation, in particular) could create a disincentive on parent companies to monitor the behaviour of their subsidiaries, because any amount of 'excessive' control might allow to conclude either that the subsidiary is merely acting as an agent of the parent, or that the implication of the parent in the operations is such that it should be held liable alongside the subsidiary. ${ }^{46}$

The case of Connelly $v$ RTZ Corporation plc serves as an illustration. ${ }^{47}$ The claimant in that case was a former employee for Rossing Uranium Ltd. (RUL), a Namibian subsidiary of the defendant corporation (RTZ Corporation plc) incorporated in the United Kingdom. The claimant had been employed by RUL in an uranium mine, following which it was discovered, three years after his return, that he was suffering from cancer of the larynx, apparently due to exposure to radioactive material in the mine. According to the description by the House of Lords, the claim was based on the allegation that 'R.T.Z. had devised R.U.L.'s policy on health, safety and the environment, or alternatively had advised R.U.L. as to the contents of the policy', and that 'an employee or employees of R.T.Z., referred to as R.T.Z. supervisors, implemented the policy and supervised health, safety and/or environmental protection at the mine'. The argument was therefore not (as in the classical veil-piercing analysis) that separation between the parent and the subsidiary should be treated as a mere fiction, a fraudulent means of limiting the liability of the parent corporation, without any

\footnotetext{
44 Mabry, note 28, 565.

45 Ibid

46 Joseph, note 38, 134, citing Andrew J Natale, 'Expansion of Parent Corporate Shareholder Liability through the Good Samaritan Doctrine: A Parent Corporation's Duty to Provide a Safe Workplace for Employees of its Subsidiary' (1988) 57 Univeristy of Cincinnati Law Review 717, 736; and Jamie Cassels, 'Outlaws: Multinational Corporations and Catastrophic Law' (2000) 31 Cumberland Law Review 311, 326.

47 Connelly v RTZ Corporation plc [1997] UKHL 30; [1998] AC 854.
} 
correspondence in economic reality: it was that RTZ corporation had itself contributed, by its acts, in causing the damage for which the victim sought compensation.

In Connelly, the direct liability of the parent corporation was asserted on the basis of the actions it had taken in defining the policies of its subsidiary. By contrast, the omissions of the parent corporation were at stake in Lubbe $v$ Cape plc, which the House of Lords was presented with again only three years later. ${ }^{48}$ Over 3,000 plaintiffs claimed damages for personal injuries (and in some cases death) allegedly suffered as the result of exposure to asbestos in South Africa, either upon working in mines owned by the defendant (until 1948) or by a fully-owned South African subsidiary of the defendant, or as a result of living in an area contaminated by the mining activities of the defendant or its subsidiaries. As noted by the leading opinion of Lord Bingham of Cornhill:

the claim is made against the defendant as a parent company which, knowing (so it is said) that exposure to asbestos was gravely injurious to health, failed to take proper steps to ensure that proper working practices were followed and proper safety precautions observed throughout the group. In this way, it is alleged, the defendant breached a duty of care which it owed to those working for its subsidiaries or living in the area of their operations (with the result that the plaintiffs thereby suffered personal injury and loss). ${ }^{49}$

In confirming the conditions under which a company owes a duty of care to its employees, the Court of Appeal in the more recent case of Chandler considered that a parent company may be liable for the conduct of its subsidiary in certain circumstances. ${ }^{50}$ Among the factors that have to be taken into account is that 'the parent knew or ought to have foreseen that the subsidiary or its employees would rely on its using that superior knowledge for the employees' protection', for the purpose of which determination 'it is not necessary to show that the parent is in the practice of intervening in the health and safety policies of the subsidiary', as it would be sufficient to show that 'the parent has a practice of intervening in the trading operations of the subsidiary, for example production and funding issues'. ${ }^{51}$ The same judgment states explicitly that the imposition of a duty of care is unrelated to the lifting of the corporate veil. $^{52}$ It is clear, however, that the two problems are closely interrelated: the imposition of a direct duty of care dispenses the victim from the burden of having to pierce the separation between the two legal entities.

\section{Comparing the Different Approaches to the Problem of the Corporate Veil}

Two important consequences follow from comparing the three approaches to overcome the problem of of the corporate veil. The first approach, based on 'derivative liability' of

\footnotetext{
48 Lubbe v Cape plc [2000] 1 WLR 1545. On 14 December 1998, the House of Lords had already refused to allow leave to the defendants for filing a further appeal against an initial decision by the Court of Appeal. Following this, over 3,000 new plaintiffs emerged, fundamentally transforming the nature of the litigation presented before the United Kingdom courts.

49 Ibid, 1550 (emphasis added).

50 Chandler $v$ Cape plc [2012] EWCA (Civ) 525. The Court of Appeal confirmed the approach of the High Court in Chandler v Cape plc [2011] EWHC 951 (QB).

51 Chandler $v$ Cape plc [2012] EWCA (Civ) 525, para. 80 (emphasis added).

52 'A subsidiary and its company are separate entities. There is no imposition or assumption of responsibility by reason only that a company is the parent company of another company'. Ibid, para. 69 .
} 
the parent corporation, creates a disincentive on the parent company to exercise a strict control over the activities of the subsidiary, even in situations where it could actually exercise such control. Indeed, to the extent that the relationships between the parent and the subsidiary remain fully consistent with the norms of corporate behaviour, i.e., do not lead to the suspicion that the parent-subsidiary separation has been misused in order to artificially insulate the parent from liability for the behaviour of the subsidiary, the corporate veil will not be pierced: only where it has been established that the control by the parent company is such that the subsidiary has no existence of its own (has no 'separate mind'), will the separation of legal personalities be disregarded. Thus, insofar as this serves to limit its potential legal liability, it will be in the interest of the parent company, not to monitor closely the everyday operations of the subsidiary, but on the contrary to abandon broad discretion to the subsidiary as to how to implement the general policies set for the multinational group.

By contrast, if — under the 'integrated enterprise' approach-we establish a presumption that the parent is liable for all the acts adopted by the subsidiaries within the multinational group, or if we seek to engage the 'direct liability' of the company for failing to exercise due diligence in controlling the activities of its subsidiary, close monitoring of the subsidiary will be in the interest of the parent: instead of making it vulnerable to attempts to pierce the corporate veil, it may be seen as a way to avoid liability or as an insurance against the risk of being accused of being negligent in exercising oversight over the subsidiary's activities.

The second consequence of this distinction is related to the question of state jurisdiction. Attempts by one state to directly regulate corporations registered under another state's jurisdiction are generally treated with the greatest suspicion, except as regards the activities of such corporations that occur on the first state's national territory. However, the extraterritorial application of the law of the forum state can be justified by the fact that the subsidiaries, although established in foreign states, in fact are controlled by the parent company, domiciled in the forum state: extraterritoriality in such cases is indirect, bring directed at the TNC as a single economic entity, or at the parent company alone. Indeed, the adoption of the 'integrated enterprise' approach or the direct liability of the multinational corporation for failure to control the subsidiary (our second and third avenues as distinguished above $)^{53}$ have an advantage over derivative liability in that they can be based on the territoriality principle, combined with the criminal law doctrine of ubiquity where the extraterritorial legislation is of a criminal nature, or at least on the active personality principle. In addition, in litigation before the US federal courts under the Alien Tort Statute (ATS) ${ }^{54}$ (provided, of course, the strong restrictions to the

\footnotetext{
53 Under the 'integrated enterprise' approach, the law of the forum state is extended to foreign corporations on the basis that they are part of one single economic group, coordinated by the parent corporation: indeed, as illustrated by the examples of the Civil Rights Act and the Americans with Disabilities Act mentioned above (see note 42), this approach has been adopted precisely in order to justify the extraterritorial reach of the concerned statutes.

54 The ATS, adopted as part of the First Judiciary Act 1789, provides that ' $[\mathrm{t}$ ] he district courts shall have original jurisdiction of any civil action by an alien for a tort only, committed in violation of the law of nations or a treaty of the United States' (28 USC \$1350). It has been interpreted to allow foreign victims to file civil liability claims against defendants over which US courts have personal jurisdiction, for violations of international norms 'accepted by the civilized world and defined with a specificity comparable to the features of the 18th-century paradigms [violation of safe conducts, infringement of the rights of ambassadors, and piracy]' which Congress had in mind when adopting the First Judiciary Act 1789. Sosa v Alvarez-Machain 542 US 692 (2004).
} 
extraterritorial impacts of the ATS as expressed in Kiobel are overcome ${ }^{55}$ ), the adoption of the 'integrated enterprise' or the 'direct liability' approaches would facilitate overcoming the barrier represented by the forum non conveniens doctrine, since the connection to the forum will be stronger if the parent company is sued directly for its own actions, rather than for those of its subsidiaries. ${ }^{56}$

For both these reasons, the most advisable solution to avoid a parent corporation from shielding itself behind the subsidiary where it would have been able to control the subsidiary more effectively, seems to consist in imposing directly on the parent corporation an obligation, defined by statute, to effectively monitor the behaviour of the subsidiaries which it 'controls'. The notion of control, for the purposes of the application of such a statutory obligation, should be defined on the basis of the stock ownership, ${ }^{57}$ without there being a need to identify, on a case-by-case basis, whether the parent company has in fact been involved in the policies of the subsidiary or whether the latter has a 'mind of its own'. Only where the parent company can demonstrate that it was unable to effectively avoid the contested behaviour of the subsidiary company from occurring, despite having exercised due diligence and despite its best efforts to seek information about such behaviour and to react accordingly, should its liability be excluded. Just like in the 'integrated enterprise' approach above, a presumption should therefore be established that the acts committed by the subsidiaries which the parent company 'controls' may be attributed to it, although such a presumption could conceivably be rebutted in certain instances where, despite the safeguards in place, the parent company failed to prevent certain tortious or otherwise illegal acts from being commited by its subsidaries.

\section{The Due Diligence Obligation: The Parent-Subsidiary and Co-contractor Relationship}

The solution proposed above to the problem of the corporate veil is fully consistent with the emphasis placed by the Guiding Principles on human rights due diligence as a component of the corporation's responsibility to respect human rights. It may be added that this solution can be relatively easily transposed on the other mode of transnationalization of a company's activities, which relies on the establishment of contractual relationships with suppliers, sub-contractors, or franchisees, rather than on an investment nexus. Where a company sources supplies from other countries, or subcontracts certain parts of a production process to contractors located abroad, it is even

\footnotetext{
55 Kiobel v Royal Dutch Petroleum Co. 569 US 12 (2013) (where the Supreme Court concludes, in a unanimous decision authored by Chief Justice Roberts, that "the presumption against extraterritoriality [of United States legislation, based on the idea that "United States law governs domestically but does not rule the world" (Microsoft Corp. v AT\&T Corp., 550 US 437, 454 (2007)], applies to claims under the ATS, and that nothing in the statute rebuts that presumption'). The concurring opinions that four Justices appended to the judgment would allow for the ATS to apply in relation to harms caused outside the US in certain limited circumstances, including when the defendant is a company incorporated in the US.

56 Joseph, note 38, 134, citing Malcolm J Rogge, 'Towards Transnational Corporate Liability in the Global Economy: Challenging the Doctrine of Forum non Conveniens in Re: Union Carbide, Alfaro, Sequihua, and Aguinda' (2001) 26 Texas International Law Journal 299, 313-14.

57 For instance, sections 747 to 756 and Schedules 24 to 26 of the United Kingdom Income and Corporation Taxes Act 1988, rely on the notion of the 'controlled foreign company', defined as a foreign company in which the resident company owns a holding of more than 50 per cent.
} 
more difficult to measure the exact degree of influence one company (for instance, the buyer or the franchisor) exercises over another company (for instance, the supplier of the franchisee). Therefore, it is particularly advantageous to define the potential liability of the buyer (or of the company sub-contracting a part of the production process) in terms that are grounded on the duty of that entity to ensure that it seeks to identify the human rights impacts of its policies and that it prevents and mitigates impacts thus identified-a duty that is independent from the reality of the influence exercised on the other economic actors with whom that entity interacts. The human rights due diligence requirement has a normative function to fulfil, which not depend on the de facto degree of control exercised by the corporation concerned on the other companies which it owns (in part or even in full) or with whom it entered into contractual relationships.

The advantages of such an approach are twofold. First, as mentioned above, this avoids the temptation for the company concerned to abstain from seeking to influence the behavior of the entities to which it is linked, by either either an investment or a contractual nexus: instead, the more it does seek to influence such behavior, the easier it will be for that company to prove that it has acted with due diligence to ensure that human rights are not negatively impacted by its activities or those of its affiliates or partners. Second, this solution contributes to legal certainty: rather than aligning the degree of responsibility of the company with the measure of the de facto influence it exercises, a measure that is always elusive and bound to be contested, such responsibility is to take all measures it can reasonably take in order to avoid negative human rights impacts. Of course, this criterion remains fact-dependent to a certain degree (since the measures a company can reasonably be expected to adopt depend on the situation of that company), and it may evolve with the practices emerging in the sector concerned (the scope of the due diligence obligation will vary in accordance with best practices within that sector). The benchmark is nevertheless more objective than one that would try to assess the reality of the influence exercised in any particular instance.

\section{The Question of Access to Remedies}

Finally, if the new legally-binding instrument were to seek to clarify the scope of the duty of states to protect human rights by regulating TNCs, it could also contribute to defining with greater precision the requirement to ensure that victims of transnational harms have access to effective remedies. The Guiding Principles provide that:

As part of their duty to protect against business-related human rights abuse, States must take appropriate steps to ensure, through judicial, administrative, legislative or other appropriate means, that when such abuses occur within their territory and/or jurisdiction those affected have access to effective remedy. (Principle 25)

The Commentary acknowledges that '[1]egal barriers that can prevent legitimate cases involving business-related human rights abuse from being addressed' include the situation ' $[w]$ here claimants face a denial of justice in a host State and cannot access home State courts regardless of the merits of the claim'. This makes it abundantly clear that Principle 25 implies a duty of the home state to provide access to remedies in its domestic courts for human rights violations occurring in a host state, whenever victims cannot have access to effective judicial remedy in that state. 
This is not a revolutionary idea. The Maastricht Principles on the Extraterritorial Obligations of States in the Area of Economic, Social and Cultural Rights, for instance, explicitly mention such a duty, ${ }^{58}$ encouraged perhaps by the examples of the ATS in the $\mathrm{US}^{59}$ and by the equivalent instrument, the so-called 'Brussels I' Regulation in the European Union. ${ }^{60}$ A 2011 report of the Office of the High Commissioner for Human Rights also refers to such a duty in the context of environmental rights. ${ }^{61}$ There is a growing concern, however, that unless states do more to remove the obstacles that victims of transnational human rights harms encounter when seeking to exercise remedies in the home state of the TNC allegedly responsible for such harms, whatever remedies may be proclaimed in principle will remain a dead letter, impossible to rely on in practice. Indeed, it is on the basis of the recognition of this fact that, when work was launched on the revision of the Brussels I Regulation, the European Commission suggested that it might be useful to include such a forum necessitatis rule, to allow proceedings to be brought before domestic courts in the European Union 'when there would otherwise be no access to justice'. ${ }^{62}$ There appears to be a broad consensus, at international level, about the need to broaden access to justice for victims of transnational harms before the courts of the home states of TNCs, where the protection provided by the courts in the host state is insufficient.

\section{A FRAMEWORK INSTRUMENT}

The second option for a new legally-binding instrument on business and human rights would take the form of a Framework Convention on Business and Human Rights.

\footnotetext{
58 Maastricht Principles, note 24, Principle 27 (Obligation to Co-operate) and Principle 37 (General Obligation to Provide Effective Remedy). As discussed further below, the duty to provide an effective remedy to victims, which, in situations where transnational human rights are concerned, is a duty both for the host state (under whose territorial jurisdiction the damage occurred) and a duty of the home state (under whose juridiction the transnational corporation is domiciled), can only be effectively discharged if the two states co-operate with one another. This explains the close link established within the Maastricht Principles between the right to an effective remedy on the one hand, and the duty of states to co-operate on the other hand.

59 See note 54.

60 Council Regulation No. 44/2001 of 22 December 2000 on jurisdiction and the recognition and enforcement of judgments in civil and commercial matters, OJ 2001 L 12/1 (now succeeded by Regulation (EU) No. 1215/2012 of the European Parliament and of the Council of 12 December 2012 on jurisdiction and the recognition and enforcement of judgments in civil and commercial matters, OJ 2012 L 351/1). For an early assessment of the potential of this instrument to ensure that EU-based transnational corporations shall be liable for human rights violations committed in their activities abroad, see Olivier De Schutter, 'The Accountability of Multinationals for Human Rights Violations in European Law' in Philip Alston (ed.), Non-State Actors and Human Rights (Oxford: Oxford University Press, 2005) 227.

61 The 'recognition of the extraterritorial obligations of States allows victims of transboundary environmental degradation, including damage to the global commons such as the atmosphere and dangerous climate change, to have access to remedies. Those who are adversely affected by environmental degradation must be able to exercise their rights, irrespective of whether the cause of environmental harm originates in their own State or beyond its boundaries and whether the cause of environmental harm lies in the activities of States or transnational corporations.' United Nations High Commissioner for Human Rights, 'Analytical Study on the Relationship between Human Rights and the Environment', A/HRC/19/34 (19 December 2011) para. 72

62 Green Paper on the Review of Council Regulation (EC) No. 44/2001 on jurisdiction and the recognition and enforcement of judgments in civil and commercial matters, COM (2009) 175 final (21 April 2009). See also Article 26 in the Proposal for a Regulation of the European Parliament and of the Council on jurisdiction and the regulation and enforcement of judgments in civil and commercial matters, COM (2010) 748 final (14 December 2010).
} 
A framework convention is one which defines general obligations of result, while leaving a broad margin of appreciation to states regarding the means of implementation as well as the speed at which to adopt the measures required. For instance, the 2003 Framework Convention on Tobacco Control (FCTC) adopted under the auspices of the World Health Organization (WHO), ${ }^{63}$ while listing a number of actions that states parties are required to take, leaves it to the states themselves to define the exact content of such measures. This freedom, however, is combined with a robust reporting process: each party should 'develop, implement, periodically update and review comprehensive multisectoral national tobacco control strategies, plans and programmes in accordance with this Convention and the protocols to which it is a Party', 64 and submit 'periodic reports on [the] implementation of [the FCTC], which should include ... information on legislative, executive, administrative or other measures taken to implement the Convention'.65

There are strong arguments in favour of such an approach being followed for the adoption of a legally-binding instrument in the area of business and human rights. First, the UN Working Group on Business and Human Rights ${ }^{66}$ already encourages all states to develop, enact, and update a national action plan on business and human rights as part of the state responsibility to disseminate and implement the Guiding Principles. The Working Group also developed guidance for the development of such action plans in December 2014, emphasizing in particular the importance of participation, ${ }^{67}$ and the International Corporate Accountability Roundtable (ICAR) and the Danish Institute for Human Rights (DIHR) have proposed a toolkit for the establishment of such plans. To date, seven states have adopted such an action plan, ${ }^{68}$ and 21 other states are in the process of finalizing one. The momentum around the adoption of such action plans may facilitate reaching a consensus on a new binding instrument making this obligatory, and establishing a systematic exchange of information between states parties around the content of such plans, thus increasing accountability.

A second argument in favour of such an approach is that it favours policy coherence. The Guiding Principles strongly emphasize the need to ensure that companies face an incentives structure that encourages them to take into account their responsibility to respect human rights (and to act accordingly), rather than to circumvent such responsibility. This requirement of coherence, under the Guiding Principles, is intended to ensure both that states have in place all the necessary policies, laws, and processes to implement their international human rights law obligations (vertical policy coherence), and that they support and equip 'departments and agencies, at both the national and subnational levels, that shape business practices-including those responsible for corporate law and securities regulation, investment, export credit and

\footnotetext{
63 WHO Framework Convention on Tobacco Control (opened for signature on 21 May 2003, entered into force on 27 February 2005) (2302 UNTS 166).

64 Ibid, Art 5.1.

65 Ibid, Art 23(a).

66 Resolution $26 / 22$, note 6.

67 Office of the High Commisisoner for Human Rights, 'State National Action Plans', http://www.ohchr.org/EN/ Issues/Business/Pages/NationalActionPlans.aspx (accessed 15 July 2015).

68 These are the United Kingdom, the Netherlands, Italy, Denmark, Spain, Finland, and Lithuania.
} 
insurance, trade and labour-to be informed of and act in a manner compatible with the Governments' human rights obligations' (horizontal policy coherence). ${ }^{69}$ The adoption by states of a comprehensive action plan ensuring a co-ordination across different policy areas and levels of governance would achieve precisely that.

Finally, a framework instrument is a tool to accelerate collective learning, and the gradual convergence on certain practices that, at the level of implementation, have proven their effectiveness. This may be particularly appropriate since certain key elements of the Guiding Principles remain vague and would require gradual clarification by systematic comparison of how they are implemented in particular settings. This is true, in particular, as regards 'due diligence' as a component of the corporate responsibility to respect human rights; the requirement to provide access to 'effective' remedies, particularly in transnational situations where the host states' courts fail to comply with requirements of independence or impartiality; or the need for states to maintain 'adequate domestic policy space to meet their human rights obligations' when they conclude trade or investment treaties or host government agreements with investors. ${ }^{70}$ However, to a certain extent, the need to ensure a consistent implementation of these notions, and to encourage states to share collective learning in this regard, are already met by the establishment of the Working Group on Business and Human Rights, which has been tasked with the follow-up to the Guiding Principles.

It may be thought that a framework instrument such as outlined here would be more acceptable to states politically, as it gives the impression of being less restrictive of states' margin of discretion in designing measures to ensure adequate protection from the human rights harms caused by TNCs. However, a framework instrument is typically quite demanding on states, since it obliges them to launch a process at domestic level that exposes them to demands from various segments of civil society. Resistance from states may emerge once they will realize the burden of such a reporting process, which goes beyond the kind of reporting to which they are already accustomed under existing United Nations human rights treaties. Moreover, in order to be effective, such a framework convention would normally require a robust follow-up mechanism at international level, in order to monitor those national-level processes: the WHO FCTC, for instance, required the establishment of a new secretariat, as well as the launching of a new peer-review process across states. The budgetary implications cannot be ignored, in a context in which governments are highly reluctant to invest more resources in international monitoring. In other terms, whereas the benefits of the establishment of a framework imposing on states a duty to report on the adoption and implementation of national action plans on

\footnotetext{
69 Guiding Principles, note 7, Commentary to Principle 8.

70 Ibid, Principle 9. Regarding the requirement that states do not make undertakings under trade or investment treaties that would create obstacles to their ability to regulate the conduct of corporations under their jurisdiction, see the 'Guiding Principles on Human Rights Impact Assessments of Trade and Investment Agreements, Report of the Special Rapporteur on the Right to Food, Olivier De Schutter: Addendum', A/HRC/19/59/Add.5 (19 December 2011). See also 'Principles for Responsible Contracts: Integrating the Management of Human Rights Risks into State-Investor Contract Negotiations: Guidance for Negotiators', A/HRC/17/31/Add.3 (25 May 2011).
} 
business and human rights could be significant, the political feasibility seems questionable.

\section{An Instrument Imposing Direct Legal Obligations on CORPORATIONS}

Although primarily focused on the strengthening of the states' duty to protect human rights, the civil society organizations who rallied behind the proposal for a new legally-binding instrument on business and human rights also refer to a third option for such an instrument. ${ }^{71}$ This option would be to conceive the new legally-binding instrument as directly addressing corporations. Such a demarche is of course reminiscent of the 2003 Draft UN Norms. ${ }^{72}$ Indeed, while the Norms ostensibly presented themselves as a restatement of the human rights obligations imposed on companies under international law, they were in fact effectuating a silent revolution by being addressed directly at companies, rather than at states alone.

It is often argued that any mechanism imposing direct obligations on companies under international law is bound to fail due to the sheer number of the actors involved: the Special Representative of the Secretary-General on Business and Human Rights, for instance, noted that 'we live in a world of ... 80,000 transnational enterprises, 10 times as many subsidiaries and countless millions of national firms, ${ }^{73}$ and the implicit suggestion is that an accountability mechanism addressed to such a large number of actors would be immediately overwhelmed by the number of instances with which it would have to deal. This argument is unconvincing. The sheer number of TNCs (however reliable that estimated number is) is not in fact an obstacle to the establishment by a new international instrument of a mechanism specifically dedicated to monitoring corporate behaviour, any more than in a domestic setting, legal prohibitions are bound to remain a dead letter because they are addressed to a large range of individuals. Indeed, such mechanisms to hold TNCs accountable already exist, to a certain extent at least. The Working Group on Business and Human Rights may receive complaints from aggrieved individuals or communities, and send communications to states or business entities on that basis in the form of urgent appeals or letters of allegation. This is also a prerogative other Special Procedures of the HRC have recognized and routinely used.

The most plausible form a new legally-binding instrument imposing direct human rights obligations on TNCs could take is that of a treaty, open to the signature and ratification of states, by which they would accept that all TNCs under their jurisdiction ${ }^{74}$

71 The Statement of the Treaty Alliance includes a paragraph stating that: 'The treaty should provide for an international monitoring and accountability mechanism. A dedicated unit or centre within the United Nations may improve the international capacity for independent research and analysis and for monitoring the practices of transnational corporations and other business enterprises. The needs and feasibility of a complementary international jurisdiction should be discussed'. Note 2 .

72 Draft UN Norms, note 12.

73 Human Rights Council, 'Report of the Special Representative of the Secretary-General on the Issue of Human Rights and Transnational Corporations and Other Business Enterprises, John Ruggie', A/HRC/17/31 (21 March 2011), para. 15.

74 'Transnational corporations under the jurisdiction' of the state concerned could be defined, for the purposes of such an instrument, as any corporation which has its centre of activity, is registered or domiciled, or has its main place of 
are subjected to some form of control, more robust than the existing monitoring mechanisms recalled above. By ratifying this instrument, for which the draft statute establishing a World Court of Human Rights could provide a source of inspiration, ${ }^{75}$ a state would express its consent to a new monitoring mechanism applying directly to the TNCs under its jurisdiction: where it is alleged that a human rights violation has been committed by a corporation, that state would agree that the corporation itself would have to respond to such allegations before an international mechanism, unless the violation has been addressed either by the internal grievance mechanisms of the corporation concerned, or through legal remedies available within the state concerned.

A treaty thus conceived could provide a significant incentive for the state to improve the remedies available in the domestic legal order to victims of corporate human rights harms, as well as for the corporations concerned to prevent, and where necessary remedy, any such harm. However, it would be important to avoid a situation in which the possibility to directly engage the responsibility of a corporation under such a mechanism would allow a state to circumvent its own specific duty to protect human rights by establishing an appropriate regulatory and policy framework. Thus, ideally, this first scenario should be seen as complementary to a reaffirmation (and perhaps a strengthening) of the duty of the state to protect human rights and at clarifying the scope of such a duty.

A mechanism such as this could be conceived by analogy with existing international criminal tribunals or the International Criminal Court (ICC), but established specifically to address serious human rights violations committed by corporations or in which corporations are complicit. This new mechanism should be of a judicial nature if it is to add value in comparison to the existing mechanisms referred to above. Under the present Rome Statute of the ICC, ${ }^{76}$ legal persons are not included in its jurisdiction. ${ }^{77}$ However, national and international legislation increasingly contemplate the criminal liability of corporations, and as recalled by a number of authors who have returned to the British and American war crimes tribunal set up after the Second World War, ${ }^{78}$ the involvement of corporations in the international crimes over which the ICC has jurisdiction can be generally imagined in the form of complicity.

(F'note continued)

business or substantial business activities, in the state concerned, or whose parent or controlling company presents such a connection to the state concerned.

75 The draft statute establishing a World Court of Human Rights was produced by a Panel of Eminent Persons appointed by the Swiss Government. Julia Kozma, Manfred Nowak, and Martin Scheinin, A World Court of Human Rights: Consolidated Statute and Commentary (Graz: Studienreihe des Ludwig Boltzmann Instituts für Menschenrechte/COST, 2010). The World Court anticipated that business entities would be allowed to recognize the jurisdiction of the Court (Art 51), which would assess human rights violations by being guided by 'the principles of the international law of State responsibility which it shall apply also in respect of Entities subject to its jurisdiction, as if the act or omission attributed to an Entity was attributable to a State' (Art 6, para. 1).

76 Rome Statute of the International Criminal Court (signed on 17 July 1998, entered into force on 1 July 2002), 2187 UNTS 3.

77 See Andrew Clapham, 'The Question of Jurisdiction Under International Criminal Law Over Legal Persons: Lessons from the Rome Conference on an International Criminal Court' in Menno T Kamminga and Saman Zia-Zarifi (eds.), Liability of Multinational Corporations under International Law (The Hague: Kluwer Law International, 2000) 139.

78 See, in particular, Anita Ramasastry, 'Corporate Complicity: From Nuremberg to Rangoon. An Examination of Forced Labor Cases and their Impact on the Liability of Multinational Corporations' (2002) 20 Berkeley Journal of International Law 91. 
For such scenarios to be viable, the instrument establishing them should address two issues that deserve a brief comment. First, it is likely that reference should be made in such an instrument either to 'serious violations of international human rights' or to violations of international humanitarian law (in the form of war crimes, crimes against humanity, genocide, or crimes of aggression), rather than to any violation of human rights by TNCs and other business enterprises. The burden that would fall on any new mechanism to be established may otherwise be seen as too heavy.

Yet, whereas violations of international humanitarian law are well circumscribed in particular as their definitions are provided in the Rome Statute, the notion of 'serious violation of international human rights law' is much more elusive. This is curious, since references to the seriousness of a violation are not unusal in human rights law. For instance, the former ' 1503 Procedure' before the United Nations Commission on Human Rights (now replaced by the Complaints Procedure before the Human Rights Council) examined situations that 'appear to reveal a consistent pattern of gross and reliable attested violations of human rights and fundamental freedoms', ${ }^{79}$ but the situations examined under that procedure were identified on an ad hoc basis, and no definition is provided of what qualifies as 'a consistent pattern of gross violation of human rights': the attempts by authors to clarify the notion illustrate the scope of disagreement. ${ }^{80}$ Similarly, the 2005 Basic Principles and Guidelines on the Right to a Remedy and Reparation for Victims of Gross Violations of International Human Rights Law and Serious Violations of International Humanitarian Law refer to 'gross' and 'serious' violations, but here again these notions remained undefined, although the Preamble states that such violations 'by their very grave nature, constitute an affront to human dignity'. 81

Three factors seem to play a role in international practice in determining the 'serious' nature of a violation of international human rights law. First, the nature of the right matters. Violations of the right to life, the right not to be subjected to torture or slavery, the right to liberty and security, freedom of expression, freedom of religion, the right to privacy, freedom of assembly, and the prohibition of systematic racial discrimination, as well as certain violations of economic, social, and cultural rights (particularly the rights to housing, health, food, and education) have all been identified as serious. ${ }^{82}$ However,

79 Economic and Social Council Resolution 1503 (XLVIII) (27 May 1970), para. 1. See now UN General Assembly 'Human Rights Council', A/Res/60/251 (mentioning that 'the Council should address situations of violations of human rights, including gross and systematic violations, and make recommendations thereon', para. 3), and Human Rights Council, 'Institution-building of the United Nations Human Rights Council', Res 5/1, Annex (establishing a complaint procedure, modeled on the former ' 1503 ' procedure, 'to address consistent patterns of gross and reliably attested violations' of human rights and fundamental freedoms, para. 85).

80 See, e.g., Felix Ermacora, 'Procedures to Deal with Human Rights Violations: A Hopeful Start in the United Nations?' (1974) 7 Revue des droits de I'homme/Human Rights Journal 670, 679; Maxime E Tardu, 'United Nations Response to Gross Violations of Human Rights: The 1503 Procedure' (1980) 20 Santa Clara Law Review 559, 583-4.

81 UN General Assembly, 'Basic Principles and Guidelines on the Right to a Remedy and Reparation for Victims of Gross Violations of International Human Rights Law and Serious Violations of International Humanitarian Law', A/Res/60/147 (16 December 2005).

82 See, inter alia, Case of Gomes Lund Et Al ('Guerrilha Do Araguaia') v Brazil (Preliminary Objections, Merits, Reparations, and Costs), Judgment, IACtHR, 24 November 2010, para. 105; Decision 1 (63) Situation in the Lao People's Democratic Republic, 21 August 2003, CERD Annual Report A/58/18 at 17, para. 2; Report on Mexico produced by the Committee on the Elimination of Discrimination against Women under Article 8 of the Optional Protocol to the Convention, and Reply from the Government of Mexico, 27 January 2005, CEDAW/C/2005/OP.8/ MEXICO at 42, para. 263; Middle East (Lebanon), SC Res. 2004, 30 August 2011; Somalia, SC Res. 2010, 30 
only the violations of the rights to life, physical integrity and liberty, and the prohibition of slavery have been identified as serious independently of the presence of any other factors. Second, a quantitative element is included in the assessment, referring to the number of victims or violations: this is often designated as the widespread or massive character of violations. Third, a violation will be deemed 'serious' due to its systematic character. For instance, systematic racial discrimination is considered to be a gross violation. ${ }^{83}$ 'Systematic' in this context means that a certain number of violations are committed in an organized manner, forming a pattern and affecting a certain number of victims. Although such systematic violations can be committed by states and by nonstate actors alike, it will be much easier to prove the systematic nature of a violation where it is condoned as an official policy. Indeed, the more 'serious' and 'systematic' the violation of human rights by such actors, the more such violation will reveal a failure by the state to discharge its duty to protect, implying that the state may be engaging its international responsibility.

This leads to the question of complicity, the other issue that any attempt to establish a new mechanism enforcing direct obligations under international law on corporations will necessarily have to address. Just like the notion of 'sphere of influence' with which it shares a common history, ${ }^{84}$ the idea of 'complicity' as applied to corporate misconduct has sometimes been criticized for its vagueness. ${ }^{85}$ The notion has been a constant preoccupation of legal doctrine since the debate on the human rights obligations of TNCs was relaunched in 1999-2000. ${ }^{86}$ It serves to identify the responsibility of companies where another entity, their business partners (suppliers or sub-contractors) or the host government commits human rights abuses, which are considered as criminal offences under either international or internal law.

There is a growing consensus that 'complicity' may take four different forms. ${ }^{87}$ It includes, first, situations where a company aided and abetted the commission

(F'note continued)

September 2011; Middle East (Syria), SC Res. 2043, 21 April 2012; Middle East (Syria), SC Res. 2042, 14 April 2012; Situation of Human Rights in Iran, GA Res. 66/175, 19 December 2011, Opp. 2. See also Theo van Boven, 'Distinguishing Criteria of Human Rights' in Karel Vasak (ed.) and Philip Alston (ed., English edition), The International Dimensions of Human Rights, Vol I (Westport, Connecticut: Greenwood Press, 1982) 43, 48.

83 Restatement (Third) of the Foreign Relations Law of the United States, note 26. Sec 702(g).

84 In the Commentary to the 'Norms on the Human Rights Responsibilities of Transnational Corporations and Other Business Enterprises' proposed by the UN Sub-Commission for the Promotion and Protection of Human Rights (note 12), corporations were expected to 'use due diligence in ensuring that their activities do not contribute directly or indirectly to human abuses, and that they do not directly or indirectly benefit from abuses of which they were aware or ought to have been aware', a responsibility that extended to all situations falling within the 'sphere of influence' of the company concerned. This implied in particular that "Transnational corporations and other business enterprises shall inform themselves of the human rights impact of their principal activities and major proposed activities so that they can further avoid complicity in human rights abuses'.

85 See, e.g., Gregory Wallace, 'Fallout from Slave-Labor Case is Troubling' (1997) 150 New Jersey Law Journal 896.

86 Useful attempts are, e.g., Andrew Clapham, 'Corporate Complicity in Violations of International Law: Beyond Unocal' in Wybo P Heere (ed.), From Government to Governance: The Growing Impact on Non-State Actors on the International and European Legal System. Proceedings of the Sixth Hague Joint Conference held in the Hague, The Netherlands, 3-5 July 2003 (The Hague: TMC Asser Press, 2004) 227; Andrew Clapham, 'State Responsibility, Corporate Responsibility, and Complicity in Human Rights Violations' in Lene Bomann-Larsen and Oddny Wiggen (eds.), Responsibility in World Business. Managing Harmful Side-Effects of Corporate Activity (Tokyo: United Nations University Press, 2004) 50; Andrew Clapham and Scott Jerbi, 'Categories of Corporate Complicity in Human Rights Abuses' (2001) 24 Hastings International and Comparative Law 339.

87 'Report of the United Nations High Commissioner on Human Rights on the Responsibilities of Transnational Corporations and Related Business Enterprises with regard to Human Rights', UN Doc E/CN.4/2005/91 (15 February 
of the violation. Under the case law of the international criminal tribunals, for instance, which in turn inspired the US federal courts' application of the ATS, such assistance will be considered to lead to a finding of complicity where it has a substantial effect on the commission of the abuse, and where it is given with the knowledge that it would have such an effect, whether or not the accomplice shares the mens rea of the direct perpetrator. ${ }^{88}$ Second, where a company is in a joint venture with the host government or with another private actor and has knowledge of, or should have known of, human rights violations committed by that partner in the fulfilment of the agreement, the company should be considered complicit in the violation for not having put an end to the business relationship. Third, a company may be said to be complicit when it benefited from the abuse, for example in instances where the state security forces repress peaceful protest against business activities. Finally, when in the face of systematic or continuous human rights violations in the host country, the company remains silent, refusing to denounce these abuses which the company was aware of or should have been aware of, we may ask whether it should not be considered the 'silent accomplice' of those violations: apart from the fact that, in such situations, direct complicity may be alleged-insofar as by remaining silent in the face of violations the company lends its moral support to those crimes, thus contributing to the instigation of such crimes ${ }^{89}$ - there exists a 'growing acceptance within companies that there is something culpable about failing to exercise influence in such circumstances' 90

Whether the agreement around these different shades of complicity is strong enough remains to be seen. If and when work is launched on a new international instrument establishing a mechanism to impose direct human rights obligations on corporations, the question will arise whether the notion of 'due diligence', given its now consensual nature, should not be preferred to the more contested notion of 'complicity'. Even if such a choice is made, however, the substantive questions arising from the fact that the corporate actor is involved in certain human rights violations without having actively caused them would have to be addressed.

\footnotetext{
(F'note continued)

2005), para. 34 (citing International Council on Human Rights Policy, Beyond Voluntarism: Human Rights and the Developing International Legal Obligations of Companies, (Geneva: ICHRP, 2002) 125-36). See also 'Report of the United Nations High Commissioner for Human Rights to the 56th Session of the General Assembly', UN Doc A/56/36 (28 September 2001) (distinguishing direct, beneficial, and silent complicity); UN Global Compact and OHCHR, 'Embedding Human Rights into Business Practice' 19, http://www.ohchr.org/Documents/Publications/Embeddingen.pdf (accessed 15 July 2015).

88 Under the ATS (note 54), it has been authoritatively held that the standard for aiding and abetting is 'knowing practical assistance or encouragement that has a substantial effect on the perpetration of the crime': John Doe I v Unocal Corp 395 F 3d 932, 945-6 (9 $9^{\text {th }}$ Cir, 2002). This standard is borrowed from the approach of international criminal tribunals. See, e.g., Prosecutor v Furundzija, IT-95-17/1-T (10 December 1998), reprinted in (1999) 38 ILM 317, where the International Criminal Tribunal for the former Yugoslavia (ICTY) held that 'the actus reus of aiding and abetting in international criminal law requires practical assistance, encouragement, or moral support which has a substantial effect on the perpetration of the crime' (at 235).

89 For instance, in the Trial Chamber judgment delivered in the case of Prosecutor $v$ Akayesu, the International Criminal Tribunal for Rwanda convicted a village mayor as an accomplice as it considered that his presence 'sent a clear signal of official tolerance for sexual violence', thus in effect encouraging the offence. Prosecutor v Akayesu, Case No. ICTR-96-4-T (Trial Chamber) (2 September 1998), §§ 693 and 694.

90 'Report of the United Nations High Commissioner for Human Rights to the 56th Session of the General Assembly', note 87 , para 111 .
} 


\section{An Instrument in Suport of Mutual Legal Assistance}

In contrast to the other avenues mentioned above, a fourth option would be strictly subsidiary to current efforts. It would target one specific obstacle to the ability of such efforts to benefit victims: the weakness of co-operation between states in providing effective remedies to victims of human rights harms that have their source in the conduct of TNCs. The lack of effective co-operation between the different states across which such corporations operate, indeed, appears as a major source of impunity in this area. In order to tackle such impunity where the activities of the TNCs cross borders, states may have to co-operate for the collection of evidence, for the freezing or seizure of assets, or for the execution of judgments. It is on this obligation of co-operation that the instrument could build.

A recent example of this problem originated in the environmental pollution caused in Peru and Ecuador by the activities of Texaco between 1964 and 1992. Although the Ecuadorian government had authorized Texaco to launch oil exploration activities in the Amazon in 1964, the massive pollution of forests and of rivers in both Ecuador and Peru led victims to file two class actions in reparation in the Southern District of New York, alleging that the pollution caused damage to their property and to their health. ${ }^{91}$ The claim was dismissed on forum non conveniens grounds. ${ }^{92}$ The victims then turned to the Ecuadorian courts, obtaining an initial judgment in Aguinda v Chevron (Chevron had succeeded Texaco in 2001) ordering the defendant company to pay over USD18 billion in compensation for the environmental damage caused. The subsequent litigation was closed by a final judgment on 12 November 2013 from the Ecuador Supreme Court finding Texaco/Chevron liable for environmental damage, although reducing the assessment of the damages to USD9.51 billion. The judgment however is still pending execution, due to the legal battle fought by Texaco/Chevron before the US courts. The case has a long and complex history, involving the reliance on international arbitration by Chevron (arguing that Ecuador had violated a bilateral investment treaty between Ecuador and the US) and accusations filed against the representatives of the Ecuadorian plaintiffs that they had been manipulating witnesses and conspired to extort damages from Chevron before Ecuadorian courts, in violation of the Racketeer Influenced and Corrupt Organizations (RICO) Act. ${ }^{93}$

This case illustrates some of the difficulties victims face in transnational cases in which corporations operating across various jurisdictions allegedly have caused, or contributed to, human rights violations. ${ }^{94}$ How could such obstacles to effective access

\footnotetext{
91 Aguinda v Texaco, Inc, 142 F.Supp 2d 534 (SDNY 2001) (claims filed by residents of the Oriente region of Ecuador suing Texaco for environmental and personal injuries that allegedly resulted from Texaco's exploitation of the region's oil fields); Ashanga $v$ Texaco Inc., SDNY Dkt. No. 94 Civ. 9266 (similar allegations made by certain residents of Peru, who live downstream from Ecuadors Oriente region).

92 Jota v Texaco, Inc 157 F.3d 153 (2d Cir 1998) (holding that dismissal on the ground of forum non conveniens, as decided by the district court, is erroneous in the absence of a condition requiring Texaco to submit to jurisdiction in Ecuador); Aguinda v Texaco, Inc $303 \mathrm{~F} 3 \mathrm{~d} 470$ (2d Cir 2002) (confirming the dismissal of the case).

9318 USC Chapter 96.

94 These obstacles were systematically collected in a report co-authored by Gwynne Skinner, Robert McCorquodale, and Olivier De Schutter, with case studies by Andie Lambe, The Third Pillar. Access to Judicial Remedies for Human Rights Violations by Transnational Business (ICAR, CORE, and ECCJ, December 2013). The appendix to the report
} 
to justice for victims be overcome? Significant progress could be achieved by setting out in detail the duties of states to co-operate in order to put an end to the impunity of corporations for human rights violations. Extraterritorial obligations of international co-operation are contained in several human rights treaties. For example, states parties to the Convention on the Rights of Persons with Disabilities, ${ }^{95}$ among the most recent of the core human rights treaties, 'recognize the importance of international co-operation and its promotion, in support of national efforts for the realization of the purpose and objectives of the present Convention' and commit to 'undertake appropriate and effective measures in this regard ...' ${ }^{96}$ A duty to co-operate for the full realization of human rights is also included in the Convention against Torture and Other Cruel, Inhuman or Degrading Treatment or Punishment, ${ }^{97}$ which requires states parties to provide each other 'the greatest measure of assistance in connection with criminal proceedings ...' relating to torture including 'the supply of all evidence at their disposal necessary for the proceedings'. ${ }^{98}$ A comparable commitment is contained in the International Convention for the Protection of all Persons from Enforced Disappearance. ${ }^{99}$ The first two Optional Protocols to the Convention on the Rights of the Child oblige states to co-operate to prevent and punish the sale of children, child prostitution, child pornography, and the involvement of children in armed conflict; they also require states to assist victims and, if they are in a position to do so, to provide financial and technical assistance for these purposes. ${ }^{100}$

The aforementioned Maastricht Principles provide in this regard that:

All States must cooperate to ensure that non-State actors do not impair the enjoyment of the economic, social and cultural rights of any persons. This obligation includes measures to prevent human rights abuses by non-State actors, to hold them to account for any such abuses, and to ensure an effective remedy for those affected. ${ }^{101}$

The implication is that, in transnational situations, states should co-operate in order to ensure that any victim of the activities of TNCs that results in a violation of human rights has access to an effective remedy, preferably of a judicial nature, in order to seek redress. A new instrument could usefully list the duties of states in this regard. ${ }^{102}$ Such a list

\footnotetext{
(F'note continued)

includes a detailed description of seven case studies that illustrate the various obstacles faced by victims of human rights violations caused by the activities of transnational corporations, stemming from the fact that such activities span across a number of jurisdictions.

95 Convention on the Rights of Persons with Disabilities (signed on 13 December 2006, entered into force 3 May 2008) 2515 UNTS 3.

96 Ibid, Art 32. The Convention also lists illustrative measures to fulfil this commitment.

97 Convention against Torture and Other Cruel, Inhuman or Degrading Treatment or Punishment (signed on 10 December 1984, entered into force 26 June 1987) 1465 UNTS 85.

98 Ibid, Art 9 (1).

99 Article 15 provides: 'States Parties shall cooperate with each other and shall afford one another the greatest measure of mutual assistance with a view to assisting victims of enforced disappearance, and in searching for, locating and releasing disappeared persons and, in the event of death, in exhuming and identifying them and returning their remains'. International Convention for the Protection of all Persons from Enforced Disappearance (signed on 20 December 2006, entered into force on 23 December 2010) 2716 UNTS 3.

100 Optional Protocol to the Convention on the Rights of the Child on the Sale of Children, Child Prostitution and Child Pornography, 2171 UNTS 227, art 10; Optional Protocol to the Convention on the Rights of the Child on the Involvement of Children in Armed Conflict, 2173 UNTS 222, Art 7.

101 Maastricht Principles, note 24, Principle 27.
} 
could include assisting foreign courts in taking evidence or statements from persons; in effecting service of judicial documents; in executing searches and seizures, in freezing evidence, in providing originals or certified copies of financial, corporate, or business records, or in identifying and tracing proceeds of crime, property, instrumentalities, or other things for evidentiary purposes; or in facilitating the voluntary appearance of persons in the requesting state. It could also include co-operating in the execution of judgments, by identifying, freezing, and tracing proceeds of crime or facilitating the recovery of assets.

An instrument focused on mutual legal assistance does not present the ideological dimension of an instrument imposing on corporations new, far-reaching human rights obligations. Nor does it create a new accountability mechanism as such: rather, it allows the mechanisms existing at domestic level, through which states discharge their duty to protect, to function more effectively, overcoming the barriers that may result from the transnational dimension of the activities of TNCs and other business enterprises as they are defined in the HRC's Resolution 26/9.

One advantage of this approach is that it would overcome what appears to be an important stumbling block in the current discussions. As all observers of the current process are well aware, the Resolution 26/9 included a footnote stating that: "“Other business enterprises" denotes all business enterprises that have a transnational character in their operational activities, and does not apply to local businesses registered in terms of relevant domestic law'. The footnote ostensibly aims to clarify the meaning of the expression 'transnational corporations or other business enterprises'. It is, however, unworkable. TNCs are simply corporations that have activities spanning different jurisdictions, either because they operate directly outside the national territory in which they are domiciled (for instance, because they have set up a branch or built a production plant in another jurisdiction), or because they own (in part or in full) a subsidiary company established in another jurisdiction, or because they are supplied by, or subcontract part of the production process or other activities, to business partners located abroad. In other words, 'TNCs' are 'business enterprises that have a transnational character in their operational activities', although they also are 'local businesses registered in terms of relevant domestic law', albeit local business that have 'transnationalized' some of their operations. As John Ruggie puts it, the definition of 'other business enterprises' proposed 'is unlikely to survive the first round of critical scrutiny and go on to serve as the basis of any viable treaty instrument'. ${ }^{103}$

However artificial and ill-informed, the dispute that arose about the footnote can be easily circumvented if the new legally-binding instrument negotiated within the IGWG established under the HRC Resolution 26/9 were to be focused on mutual legal assistance. Indeed, by the very nature of the obligations it would impose, such an instrument would only apply, in fact, to businesses whose activities are far-reaching

\footnotetext{
102 In order to clarify what might be included in a new international instrument providing for legal mutual assistance to combat human rights violations by transnational corporations, inspiration may be found in Chapter IV of the UN Convention against Corruption (UNCAC) (opened for signature on 31 October 2003, entered into force on 14 December 2005) 2349 UNTS 41.

103 John Ruggie, 'Quo Vadis? Unsolicited Advice to Business and Human Rights Treaty Sponsors' (9 September 2014), http://www.ihrb.org/commentary/quo-vadis-unsolicited-advice-business.html (accessed 20 July 2015).
} 
enough to reach outside the jurisdiction in which they are established. The diplomats would not have to quarrel about ways to avoid the local grocery store or the shoemaker at the corner of the street having to worry about the prescriptions of the new treaty: only if these actors develop business relationships abroad or own stock in foreign companies, would the treaty be of any potential relevance to them.

\section{Conclusion}

Some of the suggestions examined above in this article, that could inspire the discussions within the IGWG, simply replicate what has already been done, although less visibly and perhaps less effectively than might be desirable: that is, the case to clarify the scope of the states' duty to protect human rights and to oblige states to present national action plans on business and human rights, the first and second options explored respectively in parts II and III. The suggestion to establish a new mechanism to monitor compliance of corporate actors with human rights obligations, our third option, may seem revolutionary; in fact, it is not without precedent, and would by no means result in moving international human rights law into entirely unchartered territory. Finally, the last option, to impose on states duties of mutual legal assistance in order to ensure adequate access to effective remedies for victims, may seem to lack ambition, and to prioritize procedure over substance. It is probably, however, the single most effective contribution that a new legally-binding instrument could make towards combating impunity of corporations for transnational human rights harms they contribute to, and it is a response tailored to the reality of the problem the international community faces.

Perhaps the most promising route is one that combines elements of the different scenarios above. Specifically, the solution that appears to achieve the best balance between what is politically feasible and what represents a true improvement for victims, may be a hybrid solution building on elements of the first and the fourth option discussed above. States may have to be reminded of their duties to protect human rights extraterritorially, by regulating the corporate actors on which they may exercise influence, even where such regulation would contribute to ensuring human rights outside their national territory. The exercise of extraterritorial jurisdiction where a state seeks to directly regulate foreign companies remains highly controversial, however, even where such foreign companies are owned, wholly or in part, by individual or legal persons that are nationals of the state concerned. The most effective means to discharge this extraterritorial duty to protect, therefore, is through parent-based extraterritorial regulation - by imposing on the parent corporation certain obligations to control its subsidiaries-, or by imposing on the company domiciled under the jurisdiction of the state concerned to monitor the supply chain to ensure that it does not entertain business relationships with partners that violate human rights. We have also noted the other advantage that such a solution presents. It allows to overcome the vexing problem of the so-called 'corporate veil': once a duty of care is imposed on the parent, requiring that it effectively controls the companies in which it owns stock, there is no need to (somewhat artificially) impute to the parent company the conduct of a subsidiary, by examining whether, as a matter of fact, the parent has influenced that conduct or not. The relevant 
question is not anymore whether such influence has been exercised in fact; it is the normative question of whether it was reasonable to expect that it should have been exercised.

A duty to protect thus conceived builds on the first pillar of the 'Protect, Respect and Remedy' framework of the Guiding Principles, while strengthening it further in the areas in which these principles either lag behind international human rights law (as is the case as regards extraterritorial human rights obligations), or remain ambiguous (as they are where the relationship of the human rights due diligence requirement to the 'corporate veil' problem is concerned). But such a duty to protect can only be discharged effectively if states co-operate with one another in order to put an end to the accountability gaps that may emerge from the ability of TNCs to operate across different national jurisdictions. A reinforcement of inter-state co-operation, based on the mutual trust of states in their respective legal systems when they seek to address human rights violations by corporate actors, is the price to pay for ensuring effective access to remedies for victims of transnational corporate harms. This is what the fourth option discussed in part $\mathrm{V}$ aims to achieve. The negotiations opened in July 2015 at the first meeting of the IGWG on the new legally binding instrument on business and human rights represent a unique opportunity to move in this direction. 